\title{
Antibiotikodun Lipido Solidozko Nanopartikulak bakterioen aurkako eraginkortasuna hobetzeko
}

\author{
(Antibiotic-loaded Solid Lipid Nanoparticles to improve \\ antibacterial efficiency)
}

\author{
Mikel Roscales ${ }^{1}$, Itziar Alkorta ${ }^{1}$, Lide Arana $^{* 2}$ \\ ${ }^{1}$ Biokimika eta Biologia Molekularra Saila, Zientzia eta Teknologia Fakultatea (UPV/EHU) \\ Sarriena Auzoa z/g, 48940 Leioa, Bizkaia \\ ${ }^{2}$ Biokimika eta Biologia Molekularra Saila, Farmazia Fakultatea (UPV/EHU), \\ Unibertsitateko Ibilbidea, 7, 01006 Vitoria-Gasteiz
}

\begin{abstract}
LABURPENA: Antibiotikoen aurkako erresistentzia duten bakterioak mundu-mailako osasun-arriskua dira gaur egun, infekzioak tratatzeko ditugun terapien eraginkortasunaren galera ekar dezaketelako. Mehatxu horri aurre egiteko modu bat eskuartean ditugun farmakoak garraio-sistema egokietan txertatzea izan daiteke, eraginkortasunaren hobekuntza eta erresistentzien agerpenaren atzeratzea ekar dezaketelako. Farmakoen garraio-sistema ezberdinen artean, Lipido Solidozko Nanopartikulek ezaugarri ezin hobeak eskaintzen dituzte, zeren eta, farmakoen disolbagarritasuna, iragazkortasuna, askapen-zinetika eta egonkortasuna bezalako ezaugarri garrantzitsuak hobetzeaz gain, toxikotasuna murrizten laguntzen baitute. Lipido Solidozko Nanopartikulak matrize lipidiko solido batez eta emultsionatzaile geruza batez osaturiko nanopartikulak dira, konposatu fisiologikoekin osatzen direnak. Dena den, farmakoen garraiosistema efizienteen garapenak nanopartikulen eta sistema biologikoen arteko elkarrekintzen ezaguera eskatzen du, eta horretarako ezinbestekoak dira ekoizpen- eta karakterizazio-metodologia egokiak. Lan honetan, Lipido Solidozko Nanopartikulen osagaiak, haiek garatzeko metodologia eta haien ezaugarrien determinazioa burutzeko modua deskribatzen dira. Gainera, orain arte argitaratutako lanei buruzko berrikuspen bat egingo da antibiotikoak Solido Lipidozko Nanopartikuletan txertatzeak bakterioen aurkako terapien eraginkortasuna nola hobetu dezakeen azaltzeko.
\end{abstract}

HITZ GAKOAK: antibiotikoak, Lipido Solidozko Nanopartikulak, farmakoen garraio sistemak, antibiotikoen aurkako erresistentzia, nanopartikulen karakterizazioa.

ABSTRACT: Antibiotic resistant bacteria are a global threat because they can contribute to the loss of the efficiency of actual therapies against infectious diseases. Maintenance of the efficiency of antibacterial drugs is crucial to overcome this problem and loading antibiotics into drug delivery systems can be a possible solution because they can improve drug efficiency and delay resistance emergence. Among all drug delivery systems, Solid Lipid Nanoparticles present optimal characteristics because apart from improving drug solubility, permeability, drug-release kinetics and stability they also help reducing drug toxicity. Solid Lipid Nanoparticles are composed of a solid lipid matrix surrounded by a surfactant monolayer that can be obtained using physiologic molecules. In order to obtain efficient drug delivery systems, it is important to understand interactions between nanoparticles and biological systems. Therefore, correct Solid Lipid Nanoparticles synthesis and characterization methods are essential. In this work, materials, production and characterization methods for Solid Lipid Nanoparticles development have been described. Besides, the state of the art of antibiotic-loaded Solid Lipid Nanoparticles is described in order to highlight the advantages of applying Solid Lipid Nanoparticles to improve antibacterial efficacy of actual antibiotic therapies.

KEYWORDS: antibiotics, Solid Lipid Nanoparticles, drug delivery systems, antibiotic resistance, nanoparticle characterization.

\footnotetext{
* Harremanetan jartzeko / Corresponding author: Lide Arana. Biokimika eta Biologia Molekularra Saila, Farmazia Fakultatea (UPV/EHU), Unibertsitateko Ibilbidea, 7, 01006 Vitoria-Gasteiz. - lide.arana@ehu.eus - https://orcid.org/0000-0002-58321339
}

Nola aipatu / How to cite: Roscales, Mikel; Alkorta, Itziar; Arana, Lide (2020). "Antibiotikodun Lipido Solidozko Nanopartikulak bakterioen aurkako eraginkortasuna hobetzekon. Ekaia, 40, 2021, 203-221. (https://doi.org/10.1387/ekaia.21873).

Jasotze-data: 2020,ekainak 30; Onartze-data: 2020, azaroak 11

ISSN 0214-9753 - eISSN 2444-3581 / (c) 2021 UPV/EHU

(i) (-) $\odot$ Lan hau Creative Commons Aitortu-EzKomertziala-LanEratorririkGabe 4.0 Nazioartekoa lizentzia baten mende dago 


\section{SARRERA}

Antibiotikoek bakterioek eragindako gaixotasun infekziosoen tratamendurako erabilera arrunta duten arren, farmako horiekin erlazionaturiko hainbat arazori aurre egin behar zaie tratamendu eraginkor bat izateko. Haien artean larriena bakterioek garatzen dituzten antibiotikoen aurkako erresistentziak dira. Munduko Osasun Erakundeak (World Health Organization, WHO) argitaratu duenez, antibiotikoen aurkako erresistentzien gorakada osasun publikoa larriki mehatxatzen duen arazoa da, medikuntza modernoaren lorpenak zalantzan jartzen dituena. Gainera, WHOk aditzera eman duenez, neurririk hartu ezean XXI. mendean garai post-antibiotikora irits gintezke, gaixotasun infekzioso ohikoenak ere hilkorrak izan litezkeen garaira [1]. Gaur egun, bakterio erresistenteek sorturiko infekzioekin urtean 700.000 pertsona hiltzen direla kalkulatzen da eta, gauzak horrela, 2050 urterako heriotza-tasa 10 milioi pertsonara igoko dela aurreikusten da [2].

Bakterio patogenoek antibiotikoen efektu hilkorrak saihesteko erabiltzen dituzten hainbat mekanismo deskribatu dira. Garrantzitsuenak honako hauek dira: (i) antibiotikoen degradazio entzimatikoa, (ii) antibiotikoaren itu-molekularen eraldaketa, (iii) antibiotikoaren zelularatzearen murriztea (porina proteinen murrizketa bidez, adibidez), (iv) antibiotikoa kanporatzeko gai diren ponpaketa proteinen gainadierazpena edo (v) biopelikulen eraketa [3].

Substantzia kaltegarrien aurkako erresistentzia-gaitasuna bereganatzea bakterioen mekanismo natural bat da, mutazio-tasa altuarekin erlazionatzen dena. Izan ere, DNAren konponketa-sistema egokirik ez duten bakterioetan erreplikazioaren akatsek edota nukleotidoen eraldaketek erresistentzia-geneen sorrera dakarte [4]. Erresistentzia geneak genomako elementu genetiko mugikorretan koka daitezke, adibidez plasmido konjugatibo edo mugikorretan, txertatze-sekuentzietan, transposoietan edota integroietan. Elementu genetiko mugikor horiek bakterio-andui ezberdinen artean sakabana daitezke, geneen transferentzia horizontala deituriko mekanismoak erabiliz [5]. Ondorioz, bakterioek antibiotikoen aurkako erresistentziageneak sortzeko eta beste bakterioekin partekatzeko gaitasuna dute.

Bestalde, antibiotikoen gehiegizko erabilerak edo erabilera okerrak bakterioen gaineko presio selektibo bat sortzen dute, bakterio erresistenteen biziraupena bultzatzen duena [6]. Era berean, antibiotikoek sortzen duten estresak erresistentzia-geneen elkartrukea, mutazioak eta birkonbinazio genetikoa areagotzen ditu, erresistentzia-geneen sorrera azkartu [7].

Arazo larri horri aurre egiteko, nagusiki bi irtenbide posible daude. Lehenengo aukera antibiotiko berrien bilaketa da, baina, zoritxarrez, antibiotiko berriekiko erresistentzia duten anduien agerpena saihestu ezina litzateke. Gainera, enpresa farmazeutikoek gero eta interes gutxiago azaltzen dute antibiotiko berrien aurkikuntzan, garapen-prozesuek inbertsio ekono- 
miko eta finantza arrisku handiegiak dakartzatelako eskaintzen duten onura ekonomikoarekin alderatuta [8].

Bigarren aukera da dagoeneko ezagutzen diren antibiotikoen ezaugarriak hobetzea, farmakoen garraioa eta administrazioa hobetzen dituzten sistemak asmatuz (Drug Delivery Systems, DDS). Sistema horien bidez, ikusi da farmakoen erdibizitza luzatzen dela, disolbagarritasuna eta iragazkortasuna handitu, askatze-zinetika luzatu, eraginkortasuna areagotu eta erresistentzia mekanismoen agerpena gutxitu [9-10].

Farmakoak garraiatzeko sistema horien artean aurkitzen dira Lipido Solidozko Nanopartikulak (Solid Lipid Nanoparticles, SLN). Nanopartikula hauek matrize lipidiko solido bat dute, gorputzeko tenperaturan solido egoeran dauden lipidoz osatua. Matrize hori emultsionatzaile moduan jokatzen duen geruza batek inguratzen du, ingurune urtsuan matrize lipidikoa egonkortuko duena [9-10].

SLNen tamaina 50-1.000 nm artean kokatzen da [9], eta farmakoak garraiatzeko ezaugarri fisiko-kimiko aproposak dituzte: gainazal/masa erlazio handia eta sistema biologikoekin elkarrekiteko gaitasuna [11]. Gainera, molekula hidrofobikoen eta hidrofilikoen txertatzeko gaitasuna erakutsi dute, biobateragarriak eta biodegradagarriak dira, eta, azkenik, garraiatzen dituzten molekulak itu-zeluletara bideratzeko gaitasuna dute [12-13].

Arestian aipaturiko ezaugarri apartak direla medio, SLNek garraiatzen dituzten farmakoen bioeskuragarritasuna eta askatze-zinetikak hobetzen dituzte, eta haien farmakozinetika optimizatu eta sor ditzaketen albo-kalteak murrizten dituzte [9].

Ikerketa batzuetan frogatu denaren arabera, antibiotikoen bakterioen aurkako efektua hobetu egin da SLNtan txertatuak izan direnean [14]. Antibiotikoaren efektuaren handitzeak, bioeskuragarritasun hobearekin eta profil farmakozinetikoaren optimizazioarekin batera, antibiotikoaren beharrezko dosia murriztuko luke, eta albo-kalteen eta erresistentzia-mekanismoen agerpena gutxituko litzateke.

Lan honetan, antibiotikoak SLNtan garraiatzeko nanopartikulek bete behar dituzten ezaugarriak aztertu dira, eta horretarako, eskuragarri dauden materialak, ekoizpen metodoak eta nanopartikulen karakterizazio-prozedurak azalduko dira. Gainera, SLNen erabilerak ekar litzakeen onurak eztabaidatuko dira, orain arte lortutako emaitza arrakastatsuenak berrikusiz.

\section{SLNEN EKOIZPENA}

\subsection{Materialak}

Arestian aipatu moduan, SLNek gorputzeko tenperaturan solido egoeran dauden lipidoz osaturiko matrize bat dute. Matrize hori molekula an- 
fipatikoz inguratzen da: alde apolarra matrize lipidikoari begira orientatzen da eta alde polarra ingurune urtsuari begira. Horrela, molekula horiek emultsionatzaile eta ko-emultsionatzaile moduan jokatzen dute, molekula apolarrak ingurune urtsu batean egonkortuz (1. irudia).

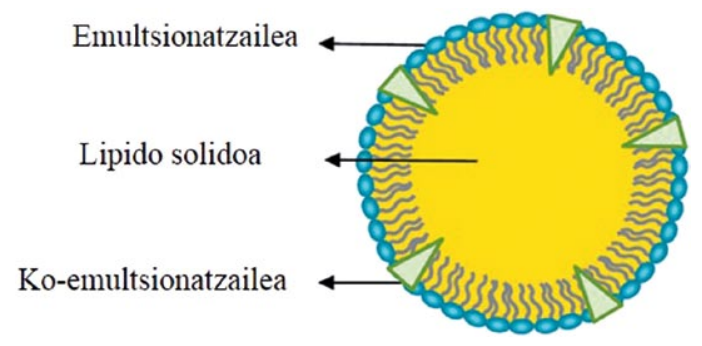

1. irudia. Lipido Solidozko Nanopartikulen egitura-ereduaren eskema. Irudian lipido solidozko matrizea (horiz) molekula emultsionatzaileak (urdinez) eta ko-emultsionatzaileak (berdez) ageri dira [12].

SLNen sintesirako erabilgarriak diren molekula ugari jadanik erabiltzen dira pilula, konprimatu eta kapsulen ekoizpenean eszipiente moduan, eta beste hainbat segurutzat jotzen diren molekula gisa (Generally Recognized As Safe, GRAS) sailkatzen dira [15]. Eranskinetako S1. eta S2. tauletan ageri dira SLNen ekoizpen-prozesuan maiztasun handiz erabiltzen diren lipido, emultsionatzaile eta ko-emultsionatzaileak.

\subsubsection{Lipido solidoaren garrantzia}

Lipido solidoa erabiltzeak farmakoen askapen-zinetika (denboran zehar nanopartikulatik askatzeko duen joera) kontrolatzea baimentzen du, eta horrela denboran zeharreko askapen sostengatua bermatzen du [16]. Hori gertatzeko arrazoia matrize solidoak farmakoari eskaintzen dion mugikortasun eskasa da, nanopartikulatik ateratzeko gaitasuna mugatuz. Ondorioz, farmakoa denbora gehiagoz mantentzen da matrizean, eta luzaroago egongo da ingurunetik babesturik [15]. Gainera, aukeratutako matrize lipidikoak farmakoarekin bateragarria izan behar du txertaketa-efizientzia ona eta farmakoaren karga egokia lortu nahi bada [17].

\subsubsection{Emultsionatzailearen eta ko-emultsionatzailearen garrantzia}

Emultsionatzaile eta ko-emultsionatzaileak molekula egonkortzaileak dira, eta matrizearen gainazal-tentsioa murrizten dute: ezinbestekoak dira esekiduraren egonkortasun fisikoarentzat. Gainera, molekula hauek izan di- 
tzaketen karga partzial edo totalek partikulen arteko aldarapen indarrak sor ditzakete, eta aglutinazio- eta hauspeatze-prozesuak saihesten dira. Egonkortasuna lortzeko kargaren zeinuak ez du garrantzirik, eta partikula kationiko zein anionikoek ekoizpena burutzea posible da, emultsionatzailearen eta ko-emultsionatzailearen hautaketa egokia dela medio (S2. taula).

\subsection{SLNen ekoizpenerako metodoak}

SLNen ekoizpenerako zenbait metodo ezagutzen dira. S3. taulan ekoizpen metodo erabilienen deskribapen txiki bat azaltzen da, haien abantaila eta desabantailekin batera. Ekoizpen-metodoak nanopartikulen oinarrizko ezaugarri fisiko-kimikoetan eragina du, haien forma, farmakoa jasotzeko nanopartikulek duten karga-gaitasuna eta partikulen egonkortasuna determinatzen dituelako [12].

Ondorioz, metodo bakoitzaren abantailak eta desabantailak kontuan hartu beharko dira ezaugarri jakin batzuetako SLNak ekoitzi nahi direnean [18]. Antibiotikodun SLNen ekoizpenari dagokionez, taularaturiko edozein metodo litzateke baliagarria.

\section{SLNEN KARAKTERIZAZIO-PROZEDURAK}

Nanopartikulen ezaugarri fisiko-kimikoek ingurune biologikoan izango duten portaera determinatzen dute. Gainera, SLNen segurtasuna eta egokitasuna ebaluatu ahal izateko eta, ondorioz, produktuaren kalitatea bermatzeko, ezinbestekoa da nanopartikula esekiduraren karakterizazio egokia burutzea [19]. Horretarako hainbat parametro hartzen dira kontuan, eta garrantzitsuenak jarraian deskribatzen dira:

\subsection{Nanopartikulen tamaina eta zeta potentziala}

Nanopartikulen tamaina eta zeta potentziala oso parametro garrantzitsuak dira nanopartikulek sistema biologikoekin izango duten portaera ulertzeko. Zeluletan barneratzeko gaitasuna, toxizitatea eta biobanaketa, esaterako, jakina da parametro horiekin erlazionatzen direla. Ezaugarri horiek neurtzeko, argiaren dispertsio dinamikoaren (Dynamic Light Scattering, DLS) determinazioa erabiltzen da [16].

Lagin batean dauden partikulen mugimenduak dispertsaturiko argiaren intentsitatean gorabeherak sortzen ditu, eta intentsitatearen fluktuazio hori neurtuz nanopartikulen erradio hidrodinamikoaren tamaina ondorioztatzea lortzen da, nanometro gutxitatik 3 mikrara bitarteko nanopartikulekin erabiltzen denean. Esan gabe doa neurketa honekin lortzen den neurria erradio hidrodinamikoarena dela, ez nanopartikularena 
berarena [18]. Esekiduran dauden nanopartikulen tamainaren homogeneitatea polidispertsitate indizearen bidez adierazten da (polydispersity index, pdi). Lagin oso monodispertsoek 0,1-etik beherako pdi balioak ematen dituzte; erdi-mailako monodispertsitatea duten laginek pdi balioak 0,1-0,4 artean izango dituzte; eta 0,4-tik gorako balioak polidispertsotzat hartzen dira [19].

Nanopartikulen zeta potentziala nanopartikularen gainazalean dagoen medioaren geruza geldikorra eta ingurunearen arteko potentzial elektrikoen arteko diferentziak ematen du [19]. Esekiduraren egonkortasunaren adierazle gisa erabiltzen da; izan ere, zenbat eta potentzial handiagoa, orduan eta aldarapen-indar handiagoak partikula ezberdinen gainazalen artean. Ondorioz, zenbat eta zeta potentzial handiagoa (zeinuak ez du axola), orduan eta hauspeatze-arrisku txikiagoa. Oro har, $\pm 30 \mathrm{mV}$-tik gorako balioak egonkortasun ona adierazten dutela onartzen da [20].

\subsection{Farmakoarekiko karga-gaitasuna eta txertaketa-efizientzia}

Nanopartikulen karakterizazio egoki batek txertatu den farmako kantitatea aztertzea eskatzen du. Karga-gaitasuna txertatutako farmako masaren eta nanopartikulen masaren arteko erlazioak ematen du, frakzio moduan edo ehunekotan adierazita (1. ekuazioa). Horretarako, beharrezkoa da ekoizpen prozesuaren ondoren aske geratu den farmakoa eta nanopartikuletan txertaturik geratu den farmakoa banatzea, zentrifugazioa, ultrafiltrazioa edo gel-iragazpeneko kromatografia erabiliz [15].

$$
\text { Karga-gaitasuna }=\frac{\text { txertatutako farmako masa }}{\text { nanopartikulen masa totala }} \times 100
$$

Farmakoaren txertaketa-efizientzia aztertzeko, aldiz, txertatu den farmako kantitatea eta aske geratu den farmako kantitatea alderatzen dira, txertatuta geratu den farmakoaren frakzioa edo ehunekoa adierazten delarik (2. ekuazioa) [18]. Karga-gaitasuna kuantifikatzerakoan bezala, txertaketa-efizientzia kalkulatzeko ere, ezinbestekoa da farmako askearen eta txertatutakoaren arteko banaketa burutzea, aurretiaz aipaturiko metodoak erabiliz. Ondoren, txertaketa-efizientzia hori modu zuzenean azter daiteke nanopartikuletako farmakoa disolbatzaileen bidez erauziz edota modu ezzuzenean, banaketaren ondoren medio urtsuan geratzen den farmako askea kuantifikatuz [21].

$$
\text { Txertaketa efizientzia }=\frac{\text { txertatutako farmako masa }}{\text { hasieran gehitutako farmako }} \times 100
$$


Farmakoen kuantifikaziorako erabili beharreko teknika farmakoaren ezaugarrien arabera hautatzen da. Dena den, teknika ohikoenak espektroskopian edo kromatografia bidezko kuantifikazioan oinarritzen dira [15].

\subsection{Egoera fisikoa eta kristal-egitura}

Nanopartikularen beste ezaugarri garrantzitsu bat matrize solidoaren kristal-egitura da, bai nanopartikulen ekoizpen prozesua-amaitzean, bai eta biltegiratzean ere. Erabilitako lipido-nahastearen eta ekoizpen-metodoaren arabera, matrizean dagoen lipidoa forma ezberdinetan kristaliza daiteke, eta horietariko batzuk ez dira egonkorrak denbora luzez [12]. Matrize lipidikoaren kristalizazioak nanopartikularen forma, karga-gaitasuna eta egonkortasuna determinatzen ditu eta, ondorioz, garrantzitsua da lipidoaren egoera fisikoaren eta kristal-egituraren karakterizazioa burutzea [18]. Gainera, neurketa hauek SLNen ekoizpen-momentuan nahiz biltegiratze-prozesuan zehar burutu behar dira, kristal-egituran gerta daitezkeen aldaketek nanopartikulen ezaugarrien eraldaketa ekar dezaketelako [12].

Lipidoaren egoera fisikoaren eta kristal-egituraren karakterizaziorako bi teknika nagusi daude, Ekorketa Kalorimetria Diferentziala (Differential Scanning Calorimetry, DSC) eta X izpien kristalografia. DSC teknikari esker fusio-puntuaren aldaketa eta fusio-prozesuaren entalpia-aldaketa determina daitezke, matrizeko lipidoaren egituraren menpeko diren bi parametro. X izpien kristalografia, aldiz, atomo arteko espazioaren determinazioan oinarritzen da, eta kristal-egituraren xehetasun gehiago jaso daitezke $[16,18]$.

\subsection{Zitotoxizitatearen azterketa in vitro}

Beste DDSekin alderatuta, SLNek duten abantaila garrantzitsuenetako bat zitotoxizitate baxua da. Hala ere, nanopartikula hutsek duten zitotoxizitatearen azterketa oinarrizkoa da segurtasuna bermatzeko. Gainera, nanopartikula hutsen eta farmakodun nanopartikulen zitotoxizitatea alderatzea garrantzitsua da farmakoaren funtzioa aztertzeko.

Gauzak horrela, nanopartikulen zitotoxizitatea aztertzeko modurik arruntena pertsona jatorriko lerro zelularrak erabiltzea da eta haien bideragarritasunean nanopartikulen kontzentrazio ezberdinek duten eragina aztertzea. Zelulak nanopartikulekin inkubatu ondoren, haien bideragarritasuna teknika ezberdinen bidez kuantifika daiteke. Teknika erabilienetako bat zelulen aktibitate metabolikoa aztertzea izaten da, 3-(4,5-dimetiltiazol-2-ilo)-2,5-difeniltetrazol bromuroaren erredukzioa kuantifikatuz. Saio hau farmako askearekin ere burutzen bada, emaitzak alderatu eta SLNak edo farmakodun SLNak gure zelulentzat kaltegarriak ote diren egiazta daiteke [14, 22-24]. 


\subsection{Farmakoaren askapen-zinetikaren determinazioa in vitro}

Askapen-zinetikan eragiten duten bi aldagai garrantzitsu nanopartikulen konposizioa eta ekoizpen-metodoak dira [15]. Horregatik, SLN berriak sintetizatzen direnean bilatzen den farmakoaren askatze iraunkorra lortzen den ala ez egiaztatu behar da.

Hau aztertzeko metodo erabiliena dialisi teknikan oinarritzen da. Teknika horretan, farmakodun SLNak dialisi zaku batean sartzen dira, eta zaku hori indargetzaile egokia duen ontzi batean hondoratzen da. Dialisi zakuak tamaina txikiko poroak ditu, eta farmakoarentzat iragazkorra da baina SLNentzat iragazkaitza. Horrela, indargetzailea gorputzeko tenperaturan $\left(37^{\circ} \mathrm{C}\right.$-an) mantentzen da etengabe irabiatuz, eta tarteka dialisi-indargetzailetik laginak hartzen dira nanopartikuletatik askatu den farmako kantitatea determinatzeko asmoz. Horrela, farmakoaren askapena eta denboraren arteko erlazioa ondoriozta daiteke, farmakoaren askapen-zinetika deritzaiona (2. irudia) [14, 22-23].
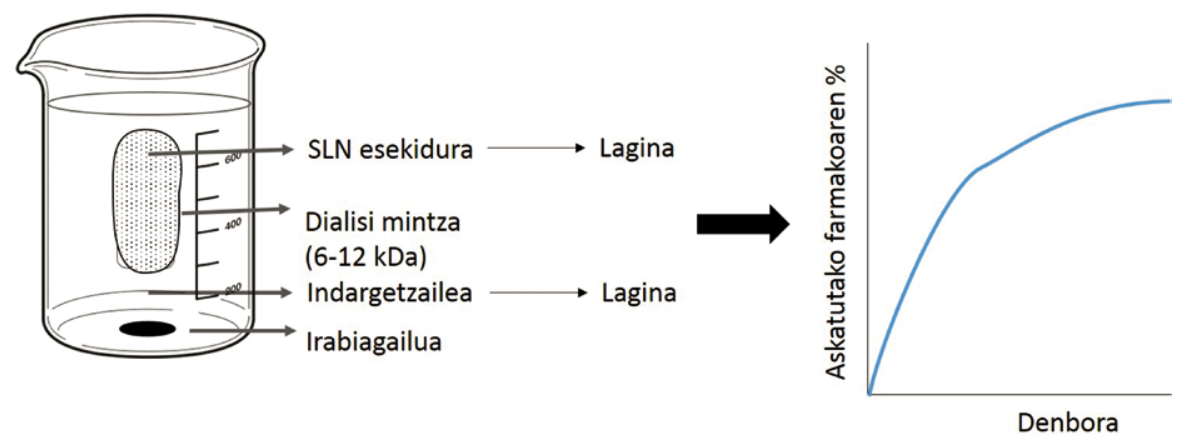

2. irudia. Askapen-zinetika lortzeko burutu beharreko saioaren eskema. Irudian SLNak dialisi-zakuaren barnean daude. Poltsa horrek tamaina txikiko poroak ditu, farmakoarentzat iragazkorrak eta SLNentzat iragazkaitzak direnak. Dialisi-zakua indargetzaile batean hondoratu eta etengabe irabiatzen da homogeneitatea mantentzeko. Tarteka laginak hartzen dira SLN esekiduratik eta indargetzailetik ateratako farmakoaren ehunekoa determinatu eta askapen-zinetikak irudikatzeko.

\subsection{Bakterioen aurkako efektua}

Antibiotikoak nanopartikuletan txertatzeak onurarik dakarren ala ez egiaztatzeko, bakterioen bideragarritasunean duen eragina azter daiteke. Ohikoena da Kontzentrazio Minimo Inhibitzailea (Minimun Inhibitory Concentration, MIC) edota Kontzentrazio Bakterizida Minimoa (Minimum Bactericidal Concentration, MBC) determinatzea. Parametro horiek anti- 
biotikoak bakterioen hazkuntza inhibitzeko behar duen kontzentrazio minimoa eta bakterioen heriotza bultzatzeko behar duen kontzentrazio minimoak adierazten dituzte, hurrenez hurren [25]. MIC kalkulatzeko metodo errazenetako bat antibiotikoaren diluzio ezberdinak prestatu eta han bakterioak inokulatu ostean bakterioen hazkuntza turbidimetria bidez kuantifikatzea da. MBC determinatzeko, sarri, antibiotikoaren kontzentrazio ezberdinetan inkubatutako bakterioak antibiotiko gabeko hazkuntza-plaketan jarri eta han koloniak sortzeko duten gaitasuna determinatzen da.

\section{SLNAK ETA BAKTERIOAK}

\subsection{SLN eta bakterioen arteko elkarrekintzak}

Bakterioekin elkarrekitean nanopartikulek erresistentzia mekanismoetan eragin dezakete, kasu batzuetan erresistentziak ezabatzera iritsiz. Orain arte burututako ikerketek erakutsi dutenez, antibiotikoak nanopartikuletan txertatzeak ahalbidetzen du (i) farmakoen kanporatze-ponpen aktibitatea murriztea, (ii) biopelikuletan barneratzeko gaitasuna handitzea, (iii) degradazio entzimatikoaren aurkako farmakoaren babesa eta (iv) zelula barneko bakteriotara iristeko gaitasuna izatea. Ezaugarri horiek antibiotikoaren eraginkortasuna handitzen dute, eta bakterioen aurkako efektua areagotu [26-27].

Ondorioz, nanopartikulen eta bakterioen arteko elkarrekintzen azterketa ezinbestekoa da antibiotikoen garraiorako interesgarrienak diren formulazioak egoki aukeratzeko. Elkarrekintza horiek aztertzeko metodorik erabilienak mikroskopia konfokala eta fluxu-zitometria dira. Bi teknika horiek zelularatzeko sarrera-bidearen inguruko eta zelula barneko kokapenaren inguruko informazioa ematen dute, mikroskopia konfokalak datu kualitatibo bidez eta fluxu-zitometriak datu semikuantitatibo bidez [28].

Teknika horien erabilerari esker, ondorioztatu da elkarrekintza elektrostatikoak garrantzitsuak direla nanopartikulen eta bakterioen arteko gertaeretan. Zehazki, nanopartikula kationikoek bakterio Gram negatiboekin elkarrekiteko gaitasun hobea dutela ikusi da, eta horren zergatia bakterio hauen kanpo-mintzeko karga negatibodun lipopolisakaridoak direla uste da. Izan ere, nanopartikula kationikoen karga positiboaren eta lipopolisakaridoen karga negatiboaren artean osatzen diren elkarrekintza elektrostatikoek nanopartikulen funtzioa hobetzen lagundu dezakete [29].

Mota honetako ikerketek nanopartikulen formulazioa hobetzen laguntzen dute, sistema eraginkorragoak lortzea erdietsiz. Horrela, emultsionatzaileen eta ko-emultsionatzaileen aukeraketaren garrantzia agerian geratzen da beste behin, azken geruza horrek determinatuko duelako partikularen karga eta ondorioz bakterio mota ezberdinekin izango dituen elkarrekintzak. 


\subsection{Antibiotikoen txertatzea SLNtan}

Jarraian, antibiotikoz kargaturiko SLN batzuen deskribapena egingo da, konposizioa eta lortutako ezaugarriak azalduko dira. Argitaratutako lan hauetan bioeskuragarritasun eskaseko baina espektro zabaleko antibiotiko ezberdinak txertatu dira SLN sistema ezberdinetan farmakoaren eraginkortasuna hobetzeko asmoz.

\subsubsection{Klaritromizina}

Klaritromizina (CLA) makrolido bat da, bakterio mota ezberdin askok eragindako gaixotasun infekziosoen tratamendurako erabilera arrunta duena. Ahoz administra daiteke, baina zenbait desabantaila ditu, hala nola, erdibizitza motza (3-4 ordu), bioeskuragarritasun eskasa eta hepatotoxizitatea [14].

Ezaugarri horiek hobetzeko asmoz, Sharmak eta haren lankideek (2016) klaritromizinadun SLNak (CLA-SLN) garatu zituzten, triestearina eta azido estearikoz osaturiko matrize lipidikoa eta soia lezitina eta Pluronic F-68 emultsionatzaileak erabilita. Nanopartikulen karakterizazio sakona egin ondoren (txertatze-efizientzia\% $84 \pm 9$, tamaina $307 \pm 23 \mathrm{~nm}$, pdi balioak 0,21 $\pm 0,04$ eta zeta potentziala $-29 \mathrm{mV}$ ) Staphylococcus aureus bakterioen hazkuntzaren Kontzentrazio Minimo Inhibitzailea (MIC) determinatu zuten. Jasotako datuen arabera, MIC balioak CLA eta CLASLNrentzat $12 \mu \mathrm{g} \mathrm{mL}^{-1}$ eta $1 \mu \mathrm{g} \mathrm{mL}^{-1}$ ziren, hurrenez hurren. Hau da, antibiotikoa SLNtan txertatzeak bakterioen aurkako efektua 12 aldiz handitzen zuen. Gainera, zitotoxizitate-frogetan ikusi zutenez, nanopartikuletan txertatzeak giza zelulen bideragarritasuna hobetzen zuen\% 76ko bideragarritasunetik\% 98ra $48 \mu \mathrm{g} \mathrm{mL}^{-1}$ nanopartikula kontzentrazioarekin inkubatu ondoren. Azkenik, saguetan egindako beste saio batzuetan ikusi zutenez, CLAren profil farmakozinetikoa eta bioeskuragarritasuna (plasmako farmakoaren kontzentrazioa) hobetzen zen nanopartikuletan txertaturik administratzen zenean. In vivo buruturiko zitotoxizitate-frogetan nekrosia behatu zuten $10 \mathrm{mg} \mathrm{kg}^{-1}$ CLA askerekin trataturiko banakoen gibelean tratamenduaren 14. Egunean, baina ez zuten nekrosi-zantzurik aurkitu CLASLN dosi berdinarekin trataturiko saguetan. Hortik, hepatotoxizitatea murrizteko CLA SLNtan txertatzea baliogarria izan daitekeela ondorioztatu zuten.

Ondorengo beste ikerketa batean, matrizeko lipidoaren izaerak CLASLNen ezaugarrietan zuen eragina aztertu zen [30]. Horretarako, hiru lipido solido ezberdin erabili zituzten matrizea osatzeko (azido estearikoa, E; glizeril behenatoa, B; tripalmitina, T) eta emultsionatzaile bakarra, Tween ${ }^{\circledR}$ 80. Lan honetako emaitzek adierazten dutenez, nanopartikulen tamaina eta pdi balioak handitu egiten ziren lipidoaren $\mathrm{C}$ atomo kopurua handitzen zen heinean. Gainera, txertatze-efizientziak ere joera bera era- 
kusten zuen, lipido handiagoek farmako hidrofobikoa bereganatzeko gaitasun handiagoa zutela iradokiz. Azkenik, S. aureus andui batean CLA askearen MIC balioa $0,5 \mu \mathrm{g} \mathrm{mL}^{-1}$ zela jakinik, T eta B-k MIC balioak 4 eta 8 aldiz handitzen zituztela ikusi zuten, E-k erdira jaisten zuen bitartean. Honen guztiaren ondoriotzat har daiteke formulazioa doitzea ezinbestekoa dela garraiatzailearen ezaugarriak optimizatzeko.

\subsubsection{Florfenikola}

Florfenikola (FFC), fenikolen taldeko molekula bakteriostatikoa, bakterio Gram positibo nahiz Gram negatiboek sortutako infekzioak tratatzeko erabiltzen den antibiotikoa da. Medio urtsuetan disolbagarritasun baxua du, erdibizitza laburra $(<3 \mathrm{~h})$ eta bioeskuragarritasun eskasa. Horrengatik guztiagatik, dosiaren maiztasuna handitu egin behar izaten da [31-32].

Ezaugarri hauek hobetzeko asmoz Wang eta haren lankideek (2015) florfenikoldun SLNak (FFC-SLN) garatu zituzten errizino olio hidrogenatua (matrize lipidikorako) eta didezilmetilamonio kloruroa (emultsionatzailea) erabiliz. Ezaugarri fisikokimikoei dagokienez, honako hau erakutsi zuten: FFC-SLNek\% 81,52 $\pm 3,37 \mathrm{ko}$ txertatze-gaitasuna, $253 \pm 3 \mathrm{~nm}$-tako tamaina, pdi $=0,409 \pm 0,022$ eta $+47,5 \pm 0,21 \mathrm{mV}$-ko zeta-potentziala.

Farmakoaren askapen zinetika eta in vitro zitotoxizitate-frogak ere egin zituzten, baina emaitza esanguratsuenak antibiotikoaren in vivo efektua aztertuz lortu zituzten. Izan ere, in vitro antibiotikoa SLNtan txertatzeak abantaila nabarmenik erakusten ez zuen arren, bakterio inokulu hilgarri baten aurrean antibiotikoa nanopartikuletan txertaturik jaso zuten arratoiek hilkortasun-tasa nabarmenki baxuagoak izan zituzten antibiotiko askea jaso zutenek baino [32]. Hortik ondoriozta daitekeena da batzuetan in vitro ezaugarriak eta in vivo ezaugarriak ez direla bat etortzen.

FFC batzuetan tilmikosina bezalako beste antibiotikoekin batera erabiltzen da, albaitaritzan bereziki. Horrela, terapia konbinatu hori nahiko ohikoa da behi mastitisa edo txerrien arnasbideetako infekzioak tratatzeko. Bi farmakoak bateratuta efektu sinergikoa lortzen da, efektu antibakterianoa handitzen da eta erresistentzien agerpena murriztu. Dena den, klinikan aplikazio eskasa du florfenikolaren aipatutako erdibizitza laburrari eta bioeskuragarritasun urriari tilmikosinaren kardiotoxizitatea gehitzen baitzaio. Horrela, eraginkorra litzatekeen dosia administratzea ezinezkoa gertatzen da klinikan [33].

Arazo horri aurre egiteko, Ling eta haren lankideek (2017) bi farmakoez kargaturiko SLNak garatu zituzten (TIL-FFC-SLN) errizino-olio hidrogenatua eta polibinilo alkohola erabiliz. TIL-FFC-SLNek farmako askeek baino bioeskuragarritasun hobea erakutsi zuten, eta posible zen 
odolean kontzentrazio eraginkorra lortzeko dosia murriztea [31, 33]. Horrela, terapia konbinatu hau klinikan aplika liteke dosi altuek eragindako zitotoxizitatea murriztuko litzatekeelako.

\subsubsection{Enrofloxazina}

Enrofloxazina (ENF) bigarren belaunaldiko antibiotiko bat da, fluorokinona mota bat. Ugaztunetan erdibizitza laburra eta ingurune urtsuan disolbagarritasun eskasa ditu. Ondorioz, bioeskuragarritasun ona izateko beharrezkoak dira dosi altuak, eta horrek toxizitatea sortzeaz gain antibiotikoen aurkako erresistentzia mekanismoen sorrera bultza dezake [34-35].

Arazo horiei aurre egiteko, konposizio ezberdineko hainbat SLN garatu ziren emultsionatzaile bakarra erabiliz (polibinilo alkohola), baina lipido solido ezberdinekin: azido estearikoa (C18), azido palmitikoa (C16) eta azido miristikoa (C14) [35].

Öztürk eta haren lankideen (2019) lanean ikusi bezala, hemen ere gantzazidoaren luzerak eragin nabarmena zuela ikusi zuten SLNen ezaugarri fisikokimikoetan. Txertatze-efizientzia eta karga-gaitasuna gantz-azidoaren luzera handitu ahala handitzen ziren, antibiotiko lipofilikoa kokatzeko gaitasun hobea zutelako [35]. Askapen-zinetikei dagokienez, konposizio guztiek atzeratzen zuten farmakoaren askapena eta odoleko kontzentrazioa handitzeko ere denek azaldu zuten gaitasuna, ziurrenik askapen-zinetika mantsoak ematen duen degradazioaren kontrako babesagatik [35].

Enrofloxazinaren erabilera ohikoena salmonelosi kasuetan izaten da, Salmonella spp-k eragiten duen infekzio intrazelularraren aurka. Antibiotiko horrek bakterioen aurkako efektu ona eta zelulan barneratzeko gaitasuna ditu, baina tratamenduaren eraginkortasuna baxua da. Izan ere, zelulek farmakoa kanporatzeko gaitasuna dutenez, kanpoko kontzentrazioa jaisten den unean zelula barneko kontzentrazioa ere asko murrizten da, eta efizientzia galdu.

Arazo hori konpontzen saiatzeko, enrofloxazinadun SLNak (ENF-SLN) garatu ziren lipido solido moduan azido behenikoa eta emultsionatzaile gisa polibinilo alkohola eta didezilmetilamonio kloruroa erabiliz. Ekoizpenprozesuko parametro ezberdinak eta emultsionatzaile kantitate ezberdinak erabiliz, ezaugarri fisiko-kimiko ezberdineko SLNak garatu ziren. Nanopartikulak karakterizatzeaz gain, lanaren helburua izan zen infekzio intrazelularrei aurre egiteko gaitasunik zuten ala ez aztertzea [36]. Horretarako, zelula immune batzuetatik eratorritako lerro zelular bat (Raw 264.7 zelulak) hartu zuten ikerketa eredu gisa, zelula barneko infekzio baten aurka antibiotikoak duen eragina bertan aztertzeko. Zelula horiek enrofloxazina gehiago barneratzen zuten ENF-SLN moduan farmako aske gisa baino, eta, ondorioz, zelula barneko kon- 
tzentrazio altuagoak lortzen ziren nanopartikulek bideratutako garraioari esker. Gainera, nanopartikulek farmakoaren kanporatzea atzeratzen zutela ikusi zuten, zelula barneko kontzentrazio egokiak luzaroago mantenduz. Hau guztia kontuan izanda, ez da harritzekoa antibiotikoaren efektuaren azterketan ENFSLN formulazioak emaitza hobeak ematea ENF askeak baino. Behatu zutenez, Salmonellarekin infektatutako Raw 264.7 zeluletan 48 h-ko inkubazio baten ostean zelula barneko bakterio kopurua\% 55 txikiagoa zen ENF-SLNrekin inkubatutako zeluletan ENF askearekin inkubatutako zeluletan baino [36] .

Ikerketa honen ondoren txerrietan burututako beste saio batzuetan ikusi zenez, ENF-SLN formulazioak ENF askeak baino farmakozinetika eta bioeskuragarritasun hobeak aurkeztu zituen [34].

\section{ONDORIOAK}

SLNak estrategia eraginkor eta berritzailea dira antibiotikoen administrazio egokiagoa lortzeko. Antibiotikoak SLNtan txertatzeak farmakoaren degradazioaren aurkako babesa, askapen-zinetika kontrolatuak, profil farmakozinetiko hobeak eta farmakoaren odol-kontzentrazio sostengatuagoa ahalbidetzen ditu. Gainera, kasu batzuetan SLNek antibiotikoaren efizientzia handitzen laguntzen dute, antibiotikoen aurkako erresistentziamekanismoak saihestuz. Bestetik, toxikotasuna murriztu dezaketela ere ikusi da, eta segurtasuna hobetu. Ezaugarri haiei guztiei esker, SLNek antibiotikoen eraginkortasuna hobetu dezakete eta horrela dosiaren murrizketa ahalbidetu. Antibiotikoak kontzentrazio eta maiztasun txikiagoarekin administratuz gero, bakterioen erresistentzia-mekanismoen agerpena atzeratzen lagundu daiteke eta horrela antibiotikoen eraginkortasunaren galerak dakarren mundu-mailako osasun-arazoa saihestu. Azkenik, konposizio ezberdineko SLNak sor daitezke metodo ezberdinak erabiliz eta horrek aukera ematen du aplikazio bakoitzerako behar diren ezaugarriak betetzen dituzten SLNak ekoizteko. Dena den, gauzak horrela, SLN sistema bakoitzaren karakterizazio sakona burutzea ezinbestekoa da haien egokitasuna bermatzeko.

\section{ESKER ONAK}

Artikulu hau Euskal Herriko Unibertsitateak finantzatutako (GIU18/229 eta COLAB19/08) eta Eusko Jaurlaritzako Ekonomiaren Garapena eta Azpiegitura Sailak finantzatutako (ELKARTEK (2020) KK-2020/00007) proiektuei esker garatu da. 


\section{BIBLIOGRAFIA}

[1] WHO. 2014. «Antimicrobial resistance. Global report on surveillance». World Health Organization.

[2] O'NEILL, J. 2015. «Tackling a global health crisis: initial steps». The Review on Antimicrobial Resistance.

[3] GAJDÁCS, M. 2019. «The concept of an ideal antibiotic: Implications for drug design». Molecules, 21, 892.

[4] OLIVER, A., CANTÓN, R., CAMPO, P., BAQUERO, F., BLÁZQUEZ, J. 2000. «High frequency of hypermutable Pseudomonas aeruginosa in cystic fibrosis lung infection». Science, 288, 1251-1253.

[5] ALÓS, J.-I. 2015. «Resistencia bacteriana a los antibióticos: una crisis global». Enfermedades Infecciosas y Microbiología Clínica, 33, 692-699.

[6] COATES, A., HU, Y., BAX, R., PAGE, C. 2002. «The future challenges facing the development of new antimicrobial drugs». Nature Reviews Drug Discovery, 1, 895-910.

[7] BAQUERO, F. 2009. «Environmental stress and evolvability in microbial systems». Clinical Microbiology and Infection, 15, 5-10.

[8] SPELLBERG, B. 2014. «The future of antibiotics». Critical Care, 18, 1-7.

[9] RAZA, A., SIME, F. B., CABOT, P. J., MAQBOOL, F., ROBERTS, J. A., FALCONER, J. R. 2019. «Solid nanoparticles for oral antimicrobial drug delivery: a review». Drug Discovery Today. 24(3), 858-866

[10] ZHANG, L., PORNPATTANANANGKUL, D., HU, C.-M., HUANG, C.-M. 2010. «Development of nanoparticles for antimicrobial drug delivery». $\mathrm{Cu}$ rrent Medicinal Chemistry, 24, 858-866.

[11] ZHANG, L., GU, F. X., CHAN, J. M., WANG, A. Z., LANGER, R. S., FAROKHZAD, O.C. 2008. «Nanoparticles in medicine: Therapeutic applications and developments». Clinical Pharmacology and Therapeutics, 83, 761-769.

[12] BAYÓN-CORDERO, L., ALKORTA, I., ARANA, L. 2019. «Application of solid lipid nanoparticles to improve the efficiency of anticancer drugs». Nanomaterials, 9, 474.

[13] BECKER PERES, L., BECKER PERES, L., DE ARAÚJO, P. H. H., SAYER, C. 2016. «Solid lipid nanoparticles for encapsulation of hydrophilic drugs by an organic solvent free double emulsion technique». Colloids and Surfaces B: Biointerfaces, 140, 317-323.

[14] SHARMA, M., GUPTA, N., GUPTA, S. 2016. «Implications of designing clarithromycin loaded solid lipid nanoparticles on their pharmacokinetics, antibacterial activity and safety». RSC Advances, 6, 76621-76631.

[15] YADAV, N., KHATAK, S., SINGH SARA, U. V. 2013. «Solid lipid nanoparticles- A review». International Journal of Applied Pharmaceutics, 5, 8-18.

[16] MEHNERT, W., MÄDER, K. 2012. «Solid lipid nanoparticles: Production, characterization and applications». Advanced Drug Delivery Reviews, 64, 83-101.

[17] DOKTOROVOVA, S., SOUTO, E. B., SILVA, A. M. 2018. «Hansen solubility parameters (HSP) for prescreening formulation of solid lipid nanopar- 
ticles (SLN): in vitro testing of curcumin-loaded SLN in MCF-7 and BT-474 cell lines». Pharmaceutical Development and Technology, 23, 93-105.

[18] GORDILlO-GALEANO, A., MORA-HUERTAS, C. E. 2018. «Solid lipid nanoparticles and nanostructured lipid carriers: A review emphasizing on particle structure and drug release». European Journal of Pharmaceutics and Biopharmaceutics, 133, 285-308.

[19] BHATTACHARJEE, S. 2016. «DLS and zeta potential - What they are and what they are not? » Journal of Controlled Release, 235, 337-351.

[20] HONARY, S., ZAHIR, F. 2013. «Effect of zeta potential on the properties of nano-drug delivery systems - A review (Part 2)». Tropical Journal of Pharmaceutical Research, 12, 265-273.

[21] ARANA, L., SALADO, C., VEGA, S., AIZPURUA-OLAIZOLA, O., ARADA, I. DE LA, SUAREZ, T., ALKORTA, I. 2015. «Solid lipid nanoparticles for delivery of Calendula officinalis extract». Colloids and Surfaces B: Biointerfaces, 135, 18-26.

[22] ROMPICHARLA, S. V. K., BHATT, H., SHAH, A., KOMANDURI, N., VIJAYASARATHY, D., GHOSH, B., BISWAS, S. 2017. «Formulation optimization, characterization, and evaluation of in vitro cytotoxic potential of curcumin loaded solid lipid nanoparticles for improved anticancer activity». Chemistry and Physics of Lipids, 208, 10-18.

[23] JAIN, A., SHARMA, G., THAKUR, K., RAZA, K., SHIVHARE, U. S., GHOSHAL, G., KATARE, O. P. 2019. «Beta-carotene-encapsulated Solid Lipid Nanoparticles (BC-SLNs) as promising vehicle for cancer: an investigative assessment». AAPS PharmSciTech, 20, 100.

[24] ÖZTÜRK, A. A., YENILMEZ, E., ARSLAN, R., ŞENEL, B., YAZAN, Y. 2020. «Dexketoprofen trometamol loaded solid lipid nanoparticles (SLNs): Formulation, in vitro and in vivo evaluation». Journal of Research in Pharmacy, 24, 82-99.

[25] WANG, T., CHEN, X., LU, M., LI, X., ZHOU, W. Z. 2015. «Preparation, characterisation and antibacterial activity of a florfenicol-loaded solid lipid nanoparticle suspension». IET Nanobiotechnology, 9, 355-361.

[26] DIAB, R., KHAMENEH, B., JOUBERT, O., DUVAL, R. 2015. «Insights in nanoparticle-bacterium interactions: New frontiers to bypass Bacterial resistance to antibiotics». Current Pharmaceutical Design, 21, 4095-4105.

[27] KHAMENEH, B., DIAB, R., GHAZVINI, K., FAZLY BAZZAZ, B. S. 2016. «Breakthroughs in bacterial resistance mechanisms and the potential ways to combat them». Microbial Pathogenesis, 95, 32-42.

[28] GONZÁlEZ-PAREDES, A., SITIA, L., RUYRA, A., MORRIS, C. J., WHEELER, G. N., MCARTHUR, M., GASCO, P. 2019. «Solid lipid nanoparticles for the delivery of anti-microbial oligonucleotides». European Journal of Pharmaceutics and Biopharmaceutics, 134, 166-177.

[29] JACOBSON, K. H., GUNSOLUS, I. L., KUECH, T. R., TROIANO, J. M., MELBY, E. S., LOHSE, S. E., PEDERSEN, J. A. 2015. «Lipopolysaccharide density and structure govern the extent and distance of nanoparticle in- 
teraction with actual and model bacterial outer membranes». Environmental Science and Technology, 49, 10642-10650.

[30] ÖZTÜRK, A. A., AYGÜL, A. ŞENEL, B. 2019. «Influence of glyceryl behenate, tripalmitin and stearic acid on the properties of clarithromycin incorporated solid lipid nanoparticles (SLNs): Formulation, characterization, antibacterial activity and cytotoxicity». Journal of Drug Delivery Science and Technology, 54, 101240.

[31] LING, Z., YONGHONG, L., JUNFENG, L., LI, Z., XIANQIANG, L. 2018. «Tilmicosin- and florfenicol-loaded hydrogenated castor oil-solid lipid nanoparticles to pigs: Combined antibacterial activities and pharmacokinetics». Journal of Veterinary Pharmacology and Therapeutics, 41, 307-313.

[32] WANG, T., CHEN, X., LU, M., LI, X., ZHOU, W. Z. 2015. «Preparation, characterisation and antibacterial activity of a florfenicol-loaded solid lipid nanoparticle suspension». IET Nanobiotechnology, 9, 355-361.

[33] LING, Z., YONGHONG, L., CHANGQING, S., JUNFENG, L., LI, Z., CHUNYU, J., XIANQIANG, L. 2017. «Preparation, characterization, and pharmacokinetics of tilmicosin- and florfenicol-loaded hydrogenated castor oil-solid lipid nanoparticles». Journal of Veterinary Pharmacology and Therapeutics, 40, 293-303.

[34] TAO, Y., YANG, F., MENG, K., CHEN, D., YANG, Y., ZHOU, K., XIE, S. 2019. «Exploitation of enrofloxacin-loaded docosanoic acid solid lipid nanoparticle suspension as oral and intramuscular sustained release formulations for pig». Drug Delivery, 26, 273-280.

[35] XIE, S., ZHU, L., DONG, Z., WANG, X., WANG, Y., LI, X., ZHOU, W. Z. 2011. «Preparation, characterization and pharmacokinetics of enrofloxacinloaded solid lipid nanoparticles: Influences of fatty acids». Colloids and Surfaces B: Biointerfaces, 83, 382-387.

[36] XIE, S., YANG, F., TAO, Y., CHEN, D., QU, W., HUANG, L., YUAN, Z. 2017. «Enhanced intracellular delivery and antibacterial efficacy of enrofloxacin-loaded docosanoic acid solid lipid nanoparticles against intracellular Salmonella». Scientific Reports, 7, 41104.

[37] MONTANA, G., BONDÌ, M. L., CARROTTA, R., PICONE, P., CRAPARO, E. F., SAN BIAGIO, P. L., DI CARLO, M. 2007. «Employment of cationic solid-lipid nanoparticles as RNA carriers». Bioconjugate Chemistry, 18, 302-308.

[38] MISHRA, V., BANSAL, K. K., VERMA, A., YADAV, N., THAKUR, S., SUDHAKAR, K., ROSENHOLM, J. M. 2018. «Solid lipid nanoparticles: Emerging colloidal nano drug delivery systems». Pharmaceutics, 10, 191.

[39] MISHRA, S., TYAGI, V. K. 2007. «Esterquats: the novel class of cationic fabric softeners». Journal of Oleo Science, 56, 269-276.

[40] KARAGÖZ, U., KOTMAKÇI, M., AKBABA, H., ÇETINTAŞ, V. B., KANTARCI, G. 2018. «Preparation and characterization of non-viral gene delivery systems with pEGFP-C1 plasmid DNA». Brazilian Journal of Pharmaceutical Sciences, 54. 


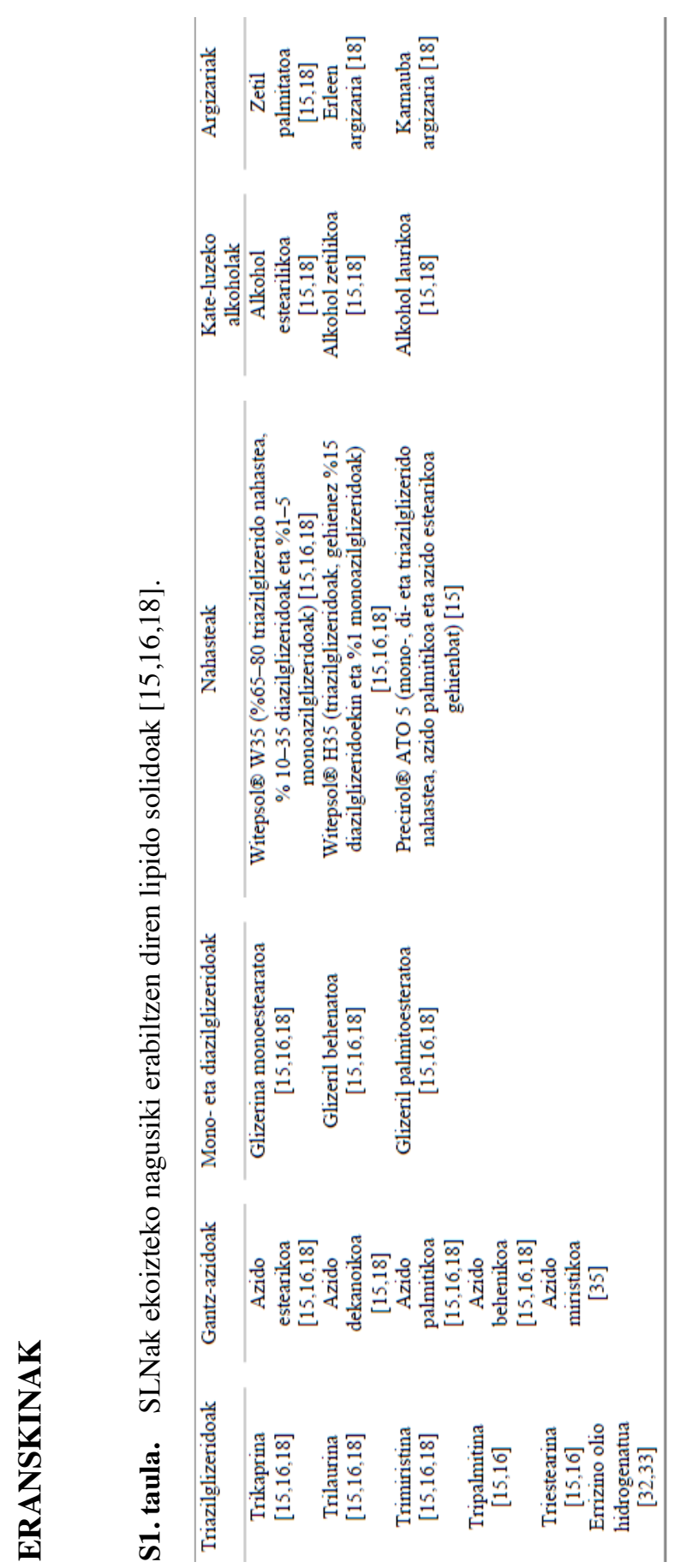




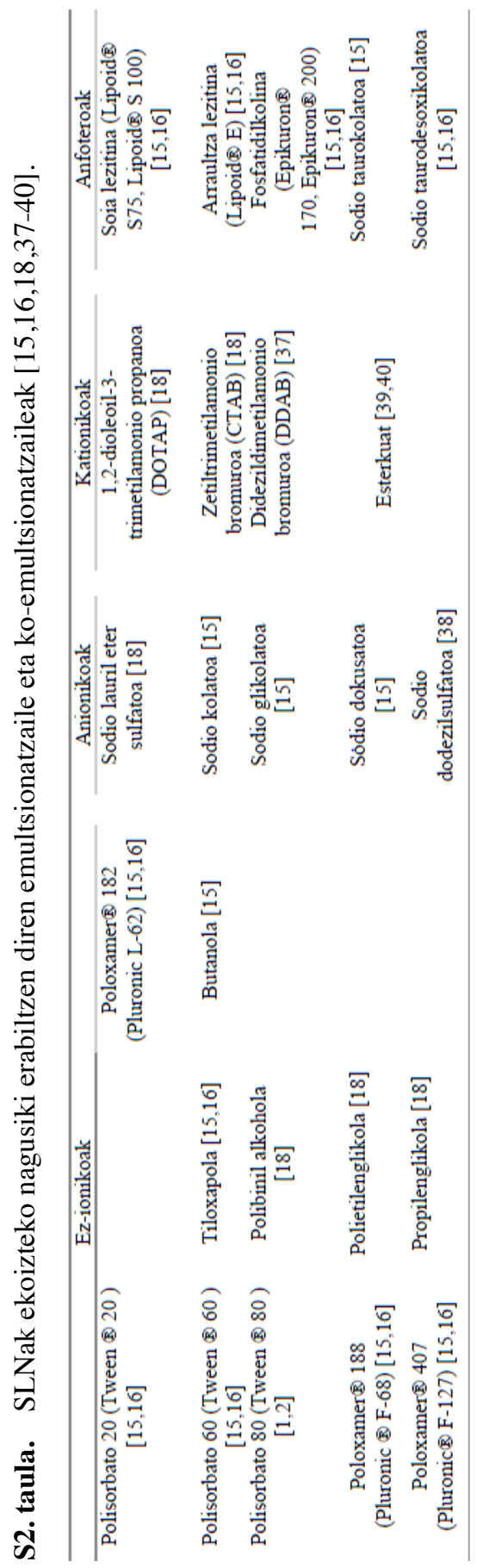




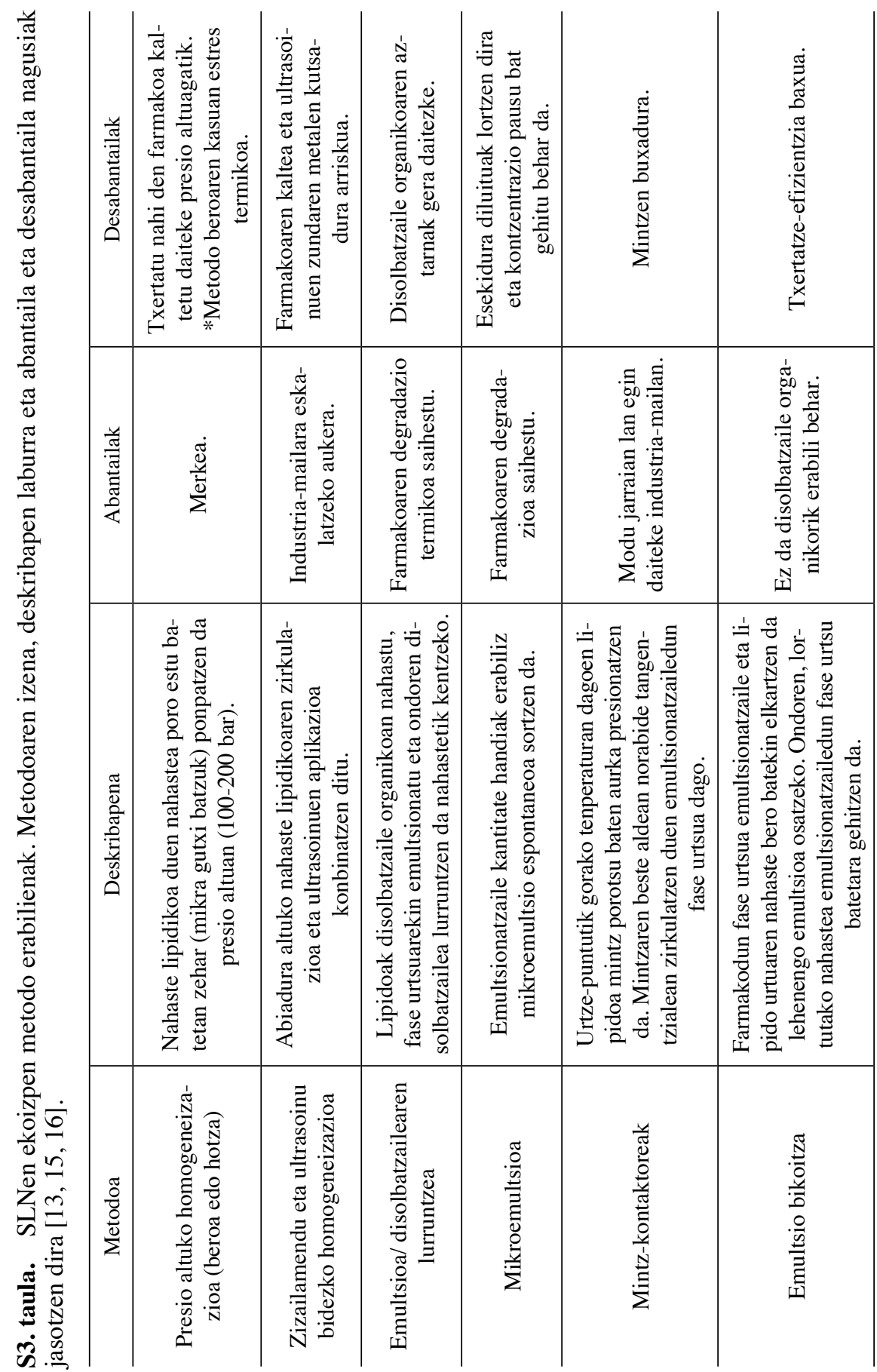


